\title{
Meningkatkan Skala UMKM Jambi dengan Penyusunan Rencana Bisnis yang Aplikatif
}

\author{
Frangky Selamat $^{1 *}$, Hetty Karunia Tunjungsari ${ }^{2}$ \\ ${ }^{12}$ Jurusan Manajemen, Universitas Tarumanagara Jakarta, Indonesia \\ Author E-mail: frangkys@fe.untar.ac.id
}

\begin{abstract}
A B S T R A K
Usaha Mikro Kecil dan Menengah (UMKM) adalah bagian terbesar dari unit usaha yang ada Indonesia. Kontribusinya terhadap Produk Domestik Bruto (PDB) juga terus meningkat dari tahun ke tahun. Walau secara kuantitas berjumlah banyak UMKM masih dapat ditingkatkan lagi dari aspek skala usaha, agar dapat memperkuat daya saing dan keberlanjutan. Untuk dapat meningkatkan skala usaha diperlukan perencanaan. Perencanaan tersebut menyangkut persiapan yang diperlukan agar usaha siap untuk tumbuh dan berkemungkinan menjadi besar. Di dalam perencanaan yang biasa disebut "business plan" pemilik usaha didorong untuk mengenal lebih dalam mengenai usaha yang dijalankan. Aspek pemasaran, penjualan, operasi, sumber daya dan keuangan menjadi fokus utama. Setiap aspek dibahas secara rinci mengenai hal yang dapat dilakukan, tidak hanya dalam jangka pendek saja, tapi juga menengah bahkan panjang. Proyeksi ke depan hendaknya dibuat berdasarkan asumsi yang masuk akal, di sinilah diperlukan kecermatan dan ketelitian di dalam menyusun rencana agar langkah-langkah yang disusun dapat dilaksanakan, tidak hanya indah di atas kertas. Hal ini yang juga ditemui pada UMKM di Provinsi Jambi. Atas dasar itu Tim Pengabdian kepada Masyarakat (PKM) bersama dengan Pusat Studi Kewirausahaan (PUSWIRA) Universitas Tarumanagara memberikan pelatihan dan pendampingan penyusunan rencana bisnis kepada 150 UMKM Jambi. Kegiatan yang berlangsung selama satu bulan yaitu pada Juli 2021 ini telah membantu pemilik UMKM menyusun rencana bisnis sederhana namun aplikatif agar usaha yang dikelola berada di jalur yang tepat untuk tumbuh dan berkelanjutan.
\end{abstract}

Kata Kunci: UMKM, Skala Usaha, Rencana Bisnis.

\section{A B S T R A C T}

Micro, Small and Medium Enterprises (MSMEs) are the largest part of Indonesia's existing business units. Its contribution to Gross Domestic Product (GDP) also continues to increase from year to year. Even though there are many MSMEs in quantity, they can still be improved from the aspect of business scale, in order to strengthen competitiveness and sustainability. To be able to increase the scale of business, planning is needed. The planning involves the necessary preparations so that the business is ready to grow and has the potential to become big. In the plan, which is usually called a "business plan", business owners are encouraged to understand more about the business they are running. Marketing, sales, operations, 
resources, and finance aspects are the main focus. Each aspect is discussed in detail about what can be done, not only in the short term, but also in the medium and even long term. The Forward projections should be based on reasonable assumptions, this is where accuracy and thoroughness are needed in preparing plans so that the steps compiled can be implemented, not only in writing. This is also found in MSMEs in Jambi Province. On this basis, the Community Service Team (PKM) together with the Center for Entrepreneurship Studies (PUSWIRA) of Tarumanagara University provided training and assistance in the preparation of business plans to 150 Jambi MSMEs. The activity, which lasted for one month, in July 2021, has helped MSME owners develop a simple but applicable business plan so that the managed business is on the right track to grow and be sustainable.

Keywords: MSME, Business Scale, Business Plan.

Copyright (c) 2021 Authors. This is an open access article distributed under the Creative Commons Attribution License, which permits unrestricted use, distribution, and reproduction in any medium, provided the original work is properly cited.

\section{PENDAHULUAN}

Kendati pandemi masih melanda Indonesia, kontribusi usaha mikro kecil dan menengah (UMKM) terhadap produk domestik bruto (PDB) mencapai 61.07\%. Pada tahun 2021 ini kontribusi diperkirakan dapat meningkat. UMKM Indonesia yang jumlahnya sekitar 64 juta usaha adalah 99\% dari keseluruhan usaha yang beroperasi. Walau kini banyak UMKM terdampak berat karena pandemi, keberadaan UMKM tidak dapat dipandang sebelah mata. Berbagai program kerja dari Kementerian Koperasi dan UKM disusun dan dijalankan agar UMKM tetap dapat bertahan, berkembang bahkan "naik kelas".

Harapan UMKM agar "naik kelas" menjadi usaha yang lebih bernilai tambah dan berdaya saing tentu harus dibarengi dengan program-program yang menyentuh hingga ke akar rumput. UMKM yang mayoritas adalah usaha perorangan dalam rangka memenuhi kebutuhan pemiliknya selayaknya memperoleh sentuhan "entrepreneurial". Pola pikir dan pandangan tentang pengelolaan sebuah usaha tentunya harus diubah perlahan.

Motivasi untuk memenuhi kebutuhan pribadi dan tidak dibarengi dengan pola pikir kewirausahaan mengakibatkan UMKM terjebak pada pengelolaan usaha yang jalan di tempat. Artinya mereka terjebak pada pemikiran bahwa usaha yang dijalankan dapat bertahan dan tidak rugi saja sudah bagus. Mayoritas belum berpikir pada rencana pengembangan. Rencana baru sebatas dari hari ke hari.

Bagi usaha yang telah eksis, penting untuk menyusun business plan (rencana bisnis). Seperti yang dikemukakan oleh Zimmerer (2008) rencana bisnis adalah dokumen tertulis yang berisi deskripsi mengenai segala aspek internal dan eksternal dari suatu usaha. Tidak juga menutup kemungkinan rencana bisnis disusun untuk keperluan pengembangan bisnis yang telah dijalankan (Slamet, 2018). Jika demikian maka usaha yang telah berjalan, seperti UMKM semestinya telah memiliki rencana bisnis.

Penyusunan rencana bisnis menjadi pijakan awal sebelum melangkah untuk dikembangkan karena merupakan peta jalan (roadmap) bagi usaha yang sukses (Kuratko \& Hornsby, 2009:76). Walau penyusunan rencana bisnis dikritik sebagai mitos karena mendorong setiap orang menyusunnya sebelum memulai usaha (Allen, 2012:234), bagi UMKM yang telah beroperasi, rencana bisnis tetap diperlukan.

Rencana bisnis juga biasa digunakan untuk menciptakan, mengkomunikasikan dan membagi pengetahuan dengan pemangku kepentingan seperti investor, bank, entitas publik, mitra potensial dan inkubator atau akselerator 
(Delmar \& Shane, 2003). Maka memasukkan pengetahuan ke dalam rencana bisnis untuk mentransfer konsep kepada pemangku kepentingan dapat menjadi isu kritis dan strategis dalam proses bisnis terutama untuk usaha rintisan (Aureli et al., 2019). Hal ini tentunya juga dilakukan untuk mengembangkan usaha di masa yang akan datang.

Harapan untuk naik kelas tentu tidak akan terwujud jika belum ada perubahan sikap mental dan langkah nyata untuk mau mengelola usaha lebih baik lagi. Dalam hal ini diperlukan penanaman orientasi kewirausahaan seperti keinovatifan (innovativeness) dan proaktif, pengambilan risiko, aggressive competitiveness dan organizational autonomy (Dess \& Lumpkin, 2005). Berdasarkan informasi di atas, tim PKM Untar berinisiatif untuk melakukan pendampingan UMKM di Jambi dalam penyusunan rencana bisnis (business plan). Tim PKM Untar juga secara bertahap mencoba menanamkan orientasi kewirausahaan sebagai bagian dari proses kewirausahaan yang berjalan.

\section{METODE PELAKSANAAN PKM}

Pelaksanaan kegiatan PKM dilakukan pada Juli 2021 dengan memberikan penyuluhan mengenai penyusunan rencana bisnis kepada 150 pemilik UMKM di Provinsi Jambi. Penyuluhan diberikan sebanyak dua kali dalam satu bulan dan diberikan berkelompok serta dilakukan secara daring dengan menggunakan Zoom Meeting. Terdapat 30 kelompok yang terlibat yang masing-masing dipandu oleh seorang dosen pendamping dan mahasiswa yang turut membantu. Satu sesi penyuluhan berlangsung selama 90 menit, yang kemudian dilanjutkan dengan pendampingan dalam penyusunan rencana bisnis. Materi yang diberikan adalah tentang prinsip kewirausahaan dan aspek penting dalam penyusunan rencana bisnis, seperti tujuan, manfaat dan aspek-aspek yang perlu dibahas di dalamnya. Setelah penyuluhan dilanjutkan dengan proses pendampingan pada setiap UMKM yang akan menyusun rencana bisnis.

\section{HASIL DAN PEMBAHASAN}

Kegiatan penyuluhan dan pendampingan penyusunan rencana bisnis UMKM Jambi dilakukan selama satu bulan yang dibagi ke dalam dua sesi untuk 30 kelompok. Sesi pertama adalah tentang rencana bisnis dengan penyusunannya dan sesi kedua mengenai pembahasan atas rencana bisnis yang telah disusun, yang kemudian dikaitkan dengan model bisnis dari tiap usaha.

Satu kelompok terdiri atas lima pemilik UMKM. Sebagian besar merupakan wanita yang juga ibu rumah tangga. Ada juga yang masih merangkap sebagai pegawai di korporasi besar atau pegawai pemerintahan di Provinsi Jambi. Terdapat pula yang masih berstatus mahasiswa dan terdorong untuk mengembangkan usaha sambil kuliah.

Motivasi sebagian pemilik UMKM ini adalah untuk menambah penghasilan akibat pemasukan utama mereka terkena dampak pandemi Covid-19. Sebagian lagi untuk menopang pendapatan rumah tangga dan ada juga yang menjadikan UMKM ini sebagai pemasukan utama.

Seperti UMKM umumnya, bidang usaha yang digeluti terkait erat dengan makanan dan minuman. Tidak ada yang bergerak dalam bidang manufaktur. Bahkan sebagian merupakan reseller, yang membeli barang dari distributor, dikemas kembali, lalu dijual kepada konsumen akhir dengan merek tertentu.

Maka jangan terlalu berharap bahwa produk yang ditawarkan menjanjikan inovasi, walau hanya yang berupa "packaging". Mayoritas adalah "pengikut" (follower) dari produk yang sudah ada. Mereka mengakui itu karena melihat pionir utama telah berhasil sehingga mendorong mereka untuk mencoba juga peruntungan dengan melakukan hal yang sama. Namun sayangnya kemunculan itu tidak dibarengi dengan penawaran "sesuatu yang baru". Mereka masih mengandalkan harga sebagai kekuatan utama untuk bersaing. Padahal keuntungan mereka pun 
masih terbatas, namun masih harus mengurangi margin keuntungan, sekadar hanya untuk bersaing.

Kehadiran tim PKM Universitas Tarumanagara bersama tim dari Pusat Studi Kewirausahaan (PUSWIRA) mencoba untuk membantu UMKM Jambi melihat kembali usaha yang dijalankan dengan mendampingi mereka menyusun rencana bisnis. Rencana bisnis menjadi instrumen penting bagi bisnis yang telah eksis ketika akan dikembangkan. Bisnis yang mau tumbuh harus dipersiapkan, dari berbagai aspek, tidak hanya aspek keuangan saja. Banyak pemilik usaha yang mengeluh terbatasnya modal keuangan yang dimiliki sehingga mereka tidak dapat meningkatkan kapasitas produksi dan meningkatkan penjualan.

Ada aspek lain yang harus dikaji ulang yaitu pasar, pemasaran, sumber daya manusia dan organisasi. Jika penjualan ditingkatkan maka harus ada permintaan pasar. Pemilik harus memastikan bahwa permintaan itu memang ada walau sebatas potensi. Pemahaman terhadap pasar harus dikuasai pemilik UMKM. Penyuluhan dan pendampingan UMKM ini memang tidak mudah dalam pelaksanaan karena harus dilakukan secara daring. Penyusunan jadwal, pemilihan waktu yang sesuai dan ketersediaan jaringan internet di tempat masing-masing.

Tidak semua pemilik UMKM bermukim di kota besar seperti kota Jambi (ibukota provinsi) tetapi ada yang di luar kota yang jaringan internetnya tidak terlalu bagus. Tidak heran jika kendala jaringan masih menjadi tantangan ketika menyelenggarakan penyuluhan secara daring. Belum lagi hampir semua peserta masih menggunakan ponsel untuk mengikuti acara yang relatif tidak terlalu kondusif jika dibandingkan laptop. Menggunakan laptop akan mendorong lebih fokus.

Dengan segala keterbatasan itu penyuluhan dijalankan, walau efektifitasnya masih dapat dipertanyakan. Semangat peserta tetap tinggi untuk memperoleh "pencerahan" dari tim PKM seperti pada gambar 1 berikut ini:

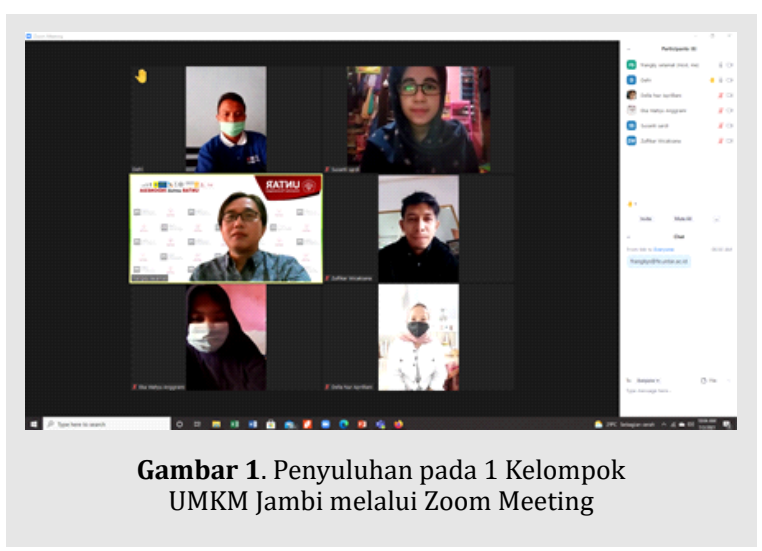

Setelah penjelasan yang ringkas tetapi padat mengenai rencana bisnis seperti yang disajikan pada gambar 2, peserta di tiap kelompok masuk ke dalam pendampingan penyusunan rencana bisnis. Bagian ini tidak mudah karena tim PKM harus menggali informasi sebanyak mungkin agar dapat membantu pemilik UMKM untuk menyusun rencana bisnis. Untuk itu tim PKM dibantu oleh 20 mahasiswa dari Program Studi Sarjana Manajemen untuk turut mendampingan pemilik UMKM menyusun rencana bisnis.

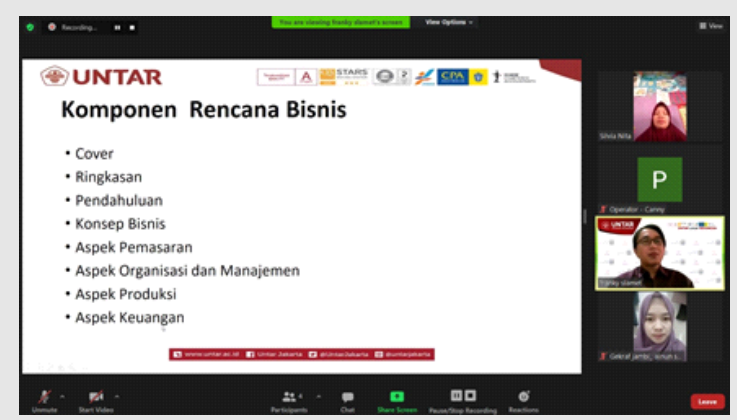

Gambar 1. Penyampaian Materi Rencana Bisnis

Hasilnya adalah seperti ditampilkan pada gambar 3 yaitu rencana bisnis sederhana dari tiap UMKM. Pada rencana bisnis yang telah disusun tersebut, memang tidak secara lengkap memuat proyeksi finansial seperti arus kas dan keuntungan. Umumnya pemilik UMKM kesulitan untuk menghitung arus kas, proyeksi laba rugi, apalagi menyusun neraca keuangan yang dapat memberikan gambaran lengkap tentang kondisi keuangan usaha. Tim PKM mencoba membantu menguraikan data keuangan yang disampaikan 
secara lisan sebagai dasar menyusun proyeksi laporan keuangan. Meski demikian dokumen yang telah disusun tetap memberikan manfaat, yaitu ada keinginan untuk mengembangkan usaha dan rencana sederhana sudah dibuat. Tinggal menjalankannya.

\section{BUSINESS PLAN}

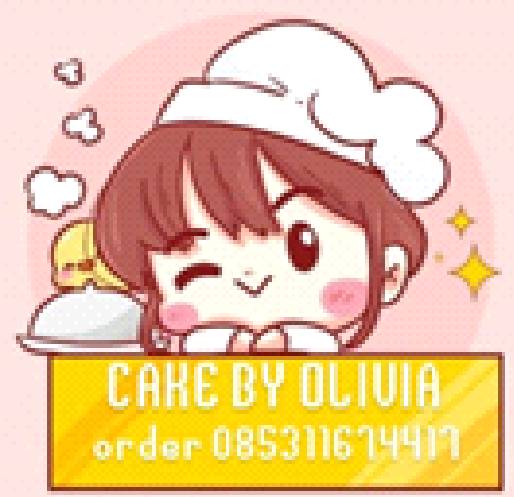

Gambar 1. Sampul Dokumen Rencana Bisnis Salah Satu Kelompok UMKM

Pada sesi berikutnya, setelah peserta menyusun rencana bisnis, tim PKM memberikan umpan balik atau tanggapan atas rencana bisnis yang telah disusun oleh pemilik UMKM. Berbagai diskusi menarik terkait pengembangan usaha hadir menyemangati mereka. Pemilik UMKM memiliki niat untuk meningkatkan skala usaha. Membuat usaha mereka lebih berkembang dan tumbuh. Namun modal niat dan semangat saja tidak cukup. Dibutuhkan juga kompetensi meramu kembali bisnis yang ada agar lebih berdaya saing dan yang tak kalah penting adalah suntikan modal kerja. Rencana bisnis yang disusun untuk pengembangan usaha menuntut tambahan modal baru seperti penggantian alat yang lebih modern, mendesain ulang promosi yang dijalankan atau mengganti kemasan dengan desain yang lebih menarik.

\section{KESIMPULAN DAN SARAN}

Secara umum kegiatan PKM dapat terlaksana dengan baik dan materi yang disampaikan memperoleh respons yang positif dari para peserta. Peserta mengikuti kegiatan dengan antusias baik selama pemaparan materi maupun pada saat sesi tanya jawab. Sesungguhnya masih terdapat peluang untuk memberikan materi penyuluhan lain kepada mitra UKM agar dapat memperkuat pemahaman mereka mengenai keterkaitan perancangan model bisnis dan penyusunan business plan, serta peluangpeluang inovasi yang dapat dieksplorasi. Di samping itu juga mengenai pengelolaan keuangan seperti arus kas, laba rugi dan neraca. Sisi pengelolaan keuangan tampaknya masih banyak yang perlu dibenahi. Bisnis yang sehat semestinya juga karena aspek keuangan yang kuat dan bukan hanya melulu menekankan pada aspek pemasaran saja.

\section{Ucapan Terima Kasih}

Terima kasih kepada UMKM Jambi yang telah menjadi mitra pelaksanaan kegiatan PKM, Pusat Studi Kewirausahaan Universitas Tarumanagara (PUSWIRA) dan LPPM yang telah memberikan dukungan dana dalam kegiatan ini. 


\section{R E F E R E N C E}

Aureli, S., Giampaoli, D., Ciambotti, M., Bontis, N. (2019). "Key factors that improve knowledge-intensive business processes which lead to competitive advantage", Business Process Management Journal, Vol. 25 No 1, pp. 126-143.

Allen, K.R. (2012). New Venture Creation, $6^{\text {th }}$ edition, Singapore: South Western, Cengage Learning.

Dess, G.G., Lumpkin G.T. (2005). "The role of entrepreneurial orientation in stimulating corporate entrepreneurship", Academy of Management Perspectives, Vol. 19, No. 1, pp 147-156.

Delmar, F., and Shane, S (2003). "Does business planning facilitate the development of new ventures?", Strategic Management Journal, Vol. 24, No 12, pp 1165-1185.

Kuratko, D.F., Hornsby, J.S. (2009). New Venture Management, Upper Saddle River, New Jersey: Pearson International Edition.

Slamet, F., Tunjungsari, H.T., Ie, M (2018). Dasar-Dasar Kewirausahaan, Teori dan Praktik, Edisi 3, Jakarta: Indeks.

Zimmerer, T.W., Scarborough., N.M. Wilson (2008). Essentials of Entrepreneurship and Small Business Management, $5^{\text {th }}$ edition, New Jersey: Prentice Hall. 